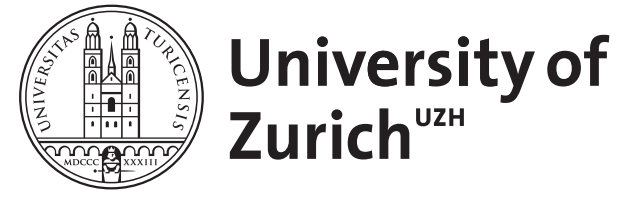

\title{
Anti-Cytokine Strategies beyond Anti-Tumour Necrosis Factor- Therapy: Pathophysiology and Clinical Implications
}

\author{
Rogler, Gerhard ; Biedermann, Luc ; Scharl, Michael
}

DOI: https://doi.org/10.1159/000449076

Posted at the Zurich Open Repository and Archive, University of Zurich ZORA URL: https://doi.org/10.5167/uzh-144724

Journal Article

Published Version

Originally published at:

Rogler, Gerhard; Biedermann, Luc; Scharl, Michael (2017). Anti-Cytokine Strategies beyond AntiTumour Necrosis Factor- Therapy: Pathophysiology and Clinical Implications. Digestive Diseases, 35(12):5-12.

DOI: https://doi.org/10.1159/000449076 


\title{
Anti-Cytokine Strategies beyond Anti-Tumour Necrosis Factor-a Therapy: Pathophysiology and Clinical Implications
}

\author{
Gerhard Rogler $^{a, b}$ Luc Biedermann ${ }^{a}$ Michael Scharl ${ }^{a, b}$ \\ ${ }^{a}$ Division of Gastroenterology and Hepatology, University Hospital Zurich, and ${ }^{\mathrm{b}}$ Zurich Center for Integrative Human \\ Physiology, University of Zurich, Zurich, Switzerland
}

\section{Key Words}

Inflammatory bowel disease - Pathophysiology .

Environmental factors $\cdot$ Hygiene hypothesis

\begin{abstract}
Cytokines are small proteins produced by a broad range of cells important in cell signaling. They include interleukins, but also chemokines, interferons, and tumor necrosis factors (TNF). They play an important role for communication between cells of the innate and adaptive immune system. The cytokine network is complex and, therefore, therapeutic interventions are difficult. The first anti-cytokine strategy successfully introduced into IBD therapy was the neutralization of TNF by antibodies. Beyond targeting this cytokine antiIL-23 strategies were demonstrated to be of therapeutic benefit in IBD. Anti-IL- 6 strategies seem to have clinical potential but also cause some risk for the patient due to the lack of CRP increase upon severe inflammation. JAK inhibitors target the intracellular signaling of several cytokine receptors and represent a promising class of broader and somewhat unspecific anti-cytokine strategies. Many other anticytokine approaches have failed due to the redundant nature of the cytokine network. Whether further anti-cytokines strategies have potential for IBD treatment may be evaluated in future studies.

(c) 2017 S. Karger AG, Basel
\end{abstract}

(c) 2017 S. Karger AG, Basel

KARGER

E-Mail karger@karger.com

www.karger.com/ddi

\section{Introduction}

Around the millennium, anti-tumour necrosis factor (TNF)- $\alpha$ antibodies have been introduced into the therapy first to treat Crohn's disease (CD) [1-8] and later on to treat ulcerative colitis (UC) [9-13]. They have significantly changed the therapeutic landscape for inflammatory bowel diseases (IBD) patients $[14,15]$.

TNF has been shown to be one of the most pathophysiological relevant pro-inflammatory factors for the pathophysiology of IBD [16-20]. Neutralization of TNF has beneficial effects in a large number of patients $[15,21,22]$. Nevertheless, there is a need for additional therapeutic options due to a non-negligible fraction of patients with primary non-response, loss of response or side-effects.

As we have shown recently in the Swiss IBD Cohort Study, surgery is still frequent in CD patients and even after 30 years, up to $80 \%$ of the patients are likely to undergo surgery $[23,24]$. The question is whether this trend changed significantly in the era of the anti-TNF antibodies. A recent study presented by Jeuring et al. [26] from the Netherlands on a Dutch population-based cohort study in the south Limburg area [25] came to a disappointing result. The disease behavior of $\mathrm{CD}$ patients diagnosed in the biological era was not different to that diagnosed in the pre-biological era [26]. CD patients 
diagnosed in the pre-biological and biological era shared a similar risk of developing structuring or penetrating disease [26]. These findings indicate that the disease phenotype and the development of the disease phenotype have not changed significantly despite changes in the CD management.

Data from the same cohort, on the other hand, showed that the number of surgeries done for just inflammatory complications has significantly decreased. This indicates that with anti-TNF antibodies we can successfully treat inflammation and all problems directly associated with inflammation. However, the processes finally leading to the penetrating and stricturing complications of the disease may be completely different. Perhaps these processes are not mainly mediated by TNF and may subsequently require different treatment options [27, 28]. The disappointing fact is that bowel damage cannot be prevented with anti-TNF therapy and this clearly indicates a need for the development of further therapies beyond current strategies.

\section{New Treatment Targets: Lessons from IBD Pathogenesis}

We generally assume that there is an uncontrolled immune reaction to endogenous and exogenous factors triggered by genetic predisposition [29-32]. A barrier defect is frequently seen as the first pathophysiological relevant problem [33, 34]. This barrier defect may be caused by a reduction of phosphatidylcholine incorporation into the mucus layer of the mucosa [35-37]. Stremmel et al. [37] have shown that the mucus layer in UC patients is decreased in thickness [38]. This has stimulated new developments for a phosphatidylcholine substitution therapy as a new therapeutic approach in UC [39-42]. So far, there is no biological therapy that can address this problem.

Among the known alterations in the barrier functions of IBD also are the differences with respect to defense in secretion as shown by the studies of Stange and Wehkamp [43--49]. The authors have attributed CD as being mainly a 'defensin-deficiency' [49] and in the case of ileal $\mathrm{CD}$, it is referred to as Paneth disease (with Paneth cells being the origin of secreted $\alpha$-defensin) [50]. Defensins certainly play a role in the barrier function of the mucosa. The differences shown for IBD patients and controls are intriguing. However, it is unclear whether the differences in defensin expression and secretion are a primary defect or a secondary response to the presence of inflammation.

In addition to the barrier defect in active IBD, there are endogenous and exogenous factors that may aggra- vate the local inflammation such as food antigens, the intestinal microbiota or environmental factors such as nanoparticles or food additives [51]. Those aggravating factors that act on an already present barrier defect may be more relevant in a genetically predisposed individual [52-54].

Genetic susceptibility has been shown to occur in genes responsible for the barrier function and also in innate immunity genes and in adaptive immunity genes [52-54]. Endogenous and exogenous factors acting on a barrier defect and innate immune defect associated with a genetic pre-disposition lead to a deregulated immune response and finally to intestinal inflammation. This means that biological therapies that mainly focus on the deregulated immune response address their target at a relatively late stage in the pathophysiological cascade that finally leads to IBD.

Nevertheless, cytokines are attractive targets for biological approaches in IBD therapy. Neurath [55] has summarized in a very nice overview article in Nature Reviews and Immunology in 2014 the cytokines that have been shown to be relevant in IBD. Important macrophagederived cytokines are interleukin (IL)-12, IL-6, IL-23 and TNF. They act on the activation and regulation of the adaptive immune system, mainly $\mathrm{T}$-cells. Important T-cell derived cytokines are interferon- $\gamma$, IL-17, IL-22 and also IL-6 and TNF [55]. Th2 cell-derived cytokines are for example IL-5 and IL-13 [55]. Cytokines secreted by regulatory T-cells are for example IL-10 and transforming growth factor $\beta$. Evidently, cytokines that are derived from regulatory $\mathrm{T}$-cells should not be antagonized, as they are anti-inflammatory by nature. In contrast, these cytokines may represent promising approaches for therapeutic substitution [55].

\section{The Promise of Precision Medicine}

With the call for 'precision medicine', doctors try to promise that in course of time we will know which patient will benefit from which therapy [56-58]. Indeed many of our IBD patients complain that they are subject to a doctor-driven 'try and error approach'. In a typical moderate-to-severe IBD patient, we may first start with immunosuppression and if this does not work within a few weeks or months, we take the next step towards administering anti-TNF therapy. If anti-TNF therapy is not successful, we may use anti-integrin strategy. If this strategy is also not successful, then we may take the next step of applying new anti-cytokines strategies. 
Precision medicine promises now that each patient should benefit from the first therapy used after a respective diagnostic approach. It is claimed that DNA tests taken before the onset of a therapy will identify the target population that benefits in all cases from a tailored therapy $[57,58]$. This indeed is a nice promise. However, in IBD it seems to be rather unrealistic. It is more and more clear - as indicated by Rappaport [59] in recent paper in PLoS One - that genetic factors are not major causes of chronic diseases. Therefore, a simple genetic test will not identify the patients that benefit most from a specific therapy. In addition, the cytokine network is extremely complex [60]. Recent manuscripts show that there are multiple backup mechanisms for every cytokine and in fact - at least for the time being - it is hard if not virtually impossible to predict which target in whom may be most promising [61, 62].

The current pipeline in adult IBD therapy is rich in product developments. In 2013, we had the pleasure to write a review on new anti-cytokines for IBD 'What is in the pipeline?' [63]. Unfortunately, $2 / 3$ of the anticytokines strategies that were in the pipeline at that time have failed and are no longer followed. However, there are several lines of development that currently seem to be quite promising.

\section{Anti IL-23 Strategies in IBD}

Sandborn et al. [64, 65] reported phase II trials of Ustekinumab in patients with moderate to severe CD. A total of 526 patients who had failed anti-TNF treatment were enrolled into the study to receive either placebo or Ustekinumab in a dosage of 1,3 or $6 \mathrm{mg} / \mathrm{kg}$ i.v. [64]. The prior endpoint of the study was the clinical response at week 6 [64]. One hundred thirty-one patients who received placebo were compared to about the same number that received the different Ustekinumab preparations. With respect to the clinical response at week 6 , there was a significant difference as compared to placebo for all concentrations used [64]. The clinical response at week 8 was highest for the $6 \mathrm{mg} / \mathrm{kg}$ dosage [64]. Remission at week 6 , however, showed no significant difference between the treatment groups and placebo. As Ustekinumab has been approved as Stelara ${ }^{\circledR}$ for the treatment for psoriasis, there was a small GETAID study published by Wils et al. [66] from Lille about the efficacy and safety of subcutaneous Ustekinumab in refractory CD patients. This was a multicenter retrospective study on off-label use of Ustekinumab in patients with desperate situations

Anti-Cytokine Strategies beyond

Anti-TNFa Therapy
[66]. One hundred thirty-five patients were recruited. Thirteen patients were excluded, as the follow-up was less than 3 months. Finally, 122 were included in the analysis. Out of those 122 patients, 79 patients (64.7\%) had a clinical benefit at 3 months [66]. Forty-three patients had a clear non-response at 3 months. Out of the 79 patients with a clinical benefit at 3 months, the majority had luminal CD [66]. Only a minority had perianal disease. However, out of 12 patients with perianal CD, 8 showed a clinical benefit [66].

Clinical response at week 6 was also the primary endpoint in the phase 3 Uniti-2 trial that most likely will lead to the approval of Ustekinumab for CD [67]. At 6 weeks, the clinical response with placebo was $28 \%$. In contrast, there was a clinical response of $51.7 \%$ with $130 \mathrm{mg}$ subcutaneously and a clinical response of $55.5 \%$ in the $6 \mathrm{mg} / \mathrm{kg}$ i.v. group [67], keeping in mind that the $6 \mathrm{mg} / \mathrm{kg}$ i.v. group also was the highest dosage group in the phase II trial that was reported earlier. After 8 weeks, the placebo response was $32 \%$, the response with the subcutaneous preparation was $47 \%$, and with the i.v. preparation, it even increased to $58 \%$ [67]. The subcutaneous preparation dosage that is used for psoriasis is $45 \mathrm{mg}$. Therefore, it appears that the dosage needed to be effective in IBD and CD is much higher as compared to psoriasis.

Is this treatment strategy effective only for Ustekinum$\mathrm{ab}$ or are there other drugs that target the same cytokine? IL-23 is a heterodimer of 2 proteins. Ustekinumab is directed against the $\mathrm{p} 40$ subunit in IL-23 that is also is present in IL-12. The second protein subunit that is in contrast to p40 specific for IL-23 is the p19 unit. Targeting IL-12 has been shown not to be successful in IBD. Therefore, it was considered that targeting the p19 subunit of IL-23 might be a more specific and promising approach. In a randomized double blind placebo controlled phase II induction study of MEDI2070, patients with active CD were dosed with anti-p19 antibody, if they had previously failed anti-TNF therapy. Sands et al. [68] have found that targeting anti-IL-23 might be successful in general and this is not restricted to anti-p40 antibodies. Targeting IL-23 alone and not IL-12 may offer a better benefit risk profile as compared with the dual inhibition of IL-12 and IL-23 by an anti-p40 antibody [68]. When Sands et al. [68] looked into the clinical efficacy in week 8 with the intention of treating population, they found that the difference with respect to CDA100 response between placebo and the antibody was $22.5 \%$. The placebo response was $26.7 \%$, whereas the drug response was $49.2 \%$. With respect to complete remission defined as a $\mathrm{CD}$ activity index (CDAI) below 150 at week 8 , the placebo response 
was $15 \%$ and the treatment response was $27.1 \%$, thereby making up a difference of $12.2 \%$, which was not statistically and significantly different with respect to composite endpoints [68]. For the composite CDAI response, there was at week 8 a difference of $32.4 \%$, which was highly significant; the placebo composite response was $10 \%$, whereas the drug response was $42.4 \%$ [68]. Also with respect to the CDAI remission composite, there was a difference of $15.4 \%$ [68]. The placebo response was $8.3 \%$ and the drug response was $23.7 \%$. This indicates that in general anti-IL-23 therapies provide a successful therapeutic strategy. We will in the near future see anti-IL-23 therapies introduced into the treatment strategy for CD.

\section{Anti-IL-6 Therapy}

The biology of IL- 6 is even more as complex as the biology of anti-IL-12 or anti-IL-23. IL-6 binds to 2 proteins to induce responses of cells. It has a specific receptor. However, the IL-6 receptor will only induce signal transduction when a second protein called gp130 is present according to the molecular weight. After binding of IL-6 to the IL- 6 receptor, a complex with 2 molecules of gp 130 is formed that finally mediates signal transduction [69, 70]. Cells that harbor only gp130 (which can also be a coreceptor for other cytokine receptors) are not responsive to IL-6 (such as epithelial cells and smooth muscle cells) [71-74]. On the other hand, hepatocytes and some leukocytes express both proteins and respond well to the cytokine [71-74].

It needs to be emphasized that the expression of IL-6 receptor in hepatocytes is essential for the formation of C-reactive protein (CRP). When IL-6 is neutralized, no stimulation of CRP production is found. There could even be severe inflammation; however, it is not indicated by increases in CRP.

In 2004, in Gastroenterology, Ito et al. [75] reported a pilot trial of tocilizumab, an anti-IL-6 antibody, in CD patients. A total of 36 patients with a CDAI higher than 150 were randomized to receive either placebo or alternating infusions of $8 \mathrm{mg} / \mathrm{kg}$ tocilizumab and placebo every 2 weeks or tocilizumab $8 \mathrm{mg} / \mathrm{kg}$ every 2 weeks [75]. The response and remission rate were evaluated at week 12. The tocilizumab infusion every 2 weeks showed a clinical response in $75 \%$ of the patients [75]. Clinical remission was seen only in the tocilizumab groups [75]. This has stimulated a number of developments with different anti-IL-6 antibodies. A development by BMS has finally been stopped during the phase II trial, as a number of bowel perforations were observed. Unfortunately, those patients showed up in emergency situations, but the severity of the complications was not realized because they did not develop sufficient CRP levels.

Pfizer has supported the ANDANTE trial. Patients could have been previously treated with anti-TNF; they were supposed to have a CDI greater than 220 but less than 450 and CRP levels above $5 \mathrm{mg} / \mathrm{l}$ [76]. A colonoscopy had to confirm the ulcerations. The patients received 3 dosings of the anti-IL- 6 antibody or placebo. One group received $10 \mathrm{mg}$ subcutaneously, one received $50 \mathrm{mg}$ and one received $200 \mathrm{mg}$ subcutaneously. The $200 \mathrm{mg}$ group stopped receiving the anti-IL-6 antibody or placebo after observing bowel perforations in another trial, which was not part of the CD trial. The patients were followed up for 28 weeks. The primary endpoint was a decrease of CDAI of 70 points or CDAI remission. At week 12, both groups were statistically significant for the $50 \mathrm{mg}$ dose [76]. There was a placebo response of $29.1 \%$ and a response of $38.3 \%$ with the $10 \mathrm{mg}$ group $(\mathrm{p}=0.19)$ and $47.6 \%$ with the $50 \mathrm{mg}$ group $(\mathrm{p}=0.045)$. With respect to CDAI remission, $11.5 \%$ achieved remission in the placebo group, $15 \%(\mathrm{p}=0.33)$ achieved remission in the $10 \mathrm{mg}$ group and $28.5 \%$ ( $\mathrm{p}=$ 0.004 ) achieved remission in the $50 \mathrm{mg}$ group. These results are quite encouraging [76]. However, at the moment it seems to be unclear whether the anti-IL-6 program will be maintained due to the risk of bowel perforation.

\section{JAK Inhibitors}

Many cytokines signal to the cells via intracellular proteins, the so-called Janus kinases or JAKs [77]. There are mainly 3 JAKs and one similar protein called Tyk 2 and they associate with different receptors. For example, the IL-6 receptor associates with JAK1, Tyk2 and JAK2. On the other hand, the IL-12 and IL-23 receptors associate with JAK2 and Tyk2 alone, whereas JAK1 does not play a role [77]. For the IL-2 receptor, signaling via JAK1 and JAK3 has been shown. Different JAK inhibitors target different JAK proteins. Ruloxitinib, Lestaurtinib, Tofacitinib and others target JAK1 and also JAK2. Tofacitinib also inhibits JAK3 [77]. For Tofacitinib, an inhibition of JAK 3 and less JAK1 and even less JAK2 have been shown.

Tofacitinib has been tested in patients with UC [78]. A total of 194 patients with active UC (Mayo score $>6$ ) received either placebo or Tofacitinib in a dosage of $0.5,3$, 10 or $15 \mathrm{mg}$ twice daily [78]. The primary endpoint in the study that was reported by Sandborn et al. [78] in the New England Journal of Medicine in 2012 was the clinical re- 
sponse with a decrease of the Mayo score of 3 points or $30 \%$ at week 8 . Tofacitinib at the dosage of $15 \mathrm{mg}$ showed a significant effect with respect to clinical response. With respect to clinical remission, which was just $10 \%$ in the placebo patients but $33 \%, 48$ or $41 \%$, respectively, in the Tofacitinib groups 3, 10 and $15 \mathrm{mg}$ of Tofacitinib showed significant effects [78]. With respect to endoscopic response, again the highest concentration was found to the most effective and it showed a significant result [78]. For endoscopic remission, again all 3 higher concentrations were effective; however, it has to be kept in mind that in this phase 2 trial, numbers were still small.

A larger trial now has confirmed the beneficial data for UC; however, in CD, the effect of Tofacitinib was not statistically significant (unpublished, presented at DDW 2015). In contrast, Filgotinib, a selective JAK1 inhibitor that revealed to be effective in rheumatoid arthritis with a planned phase 3 program in this indication, was shown to be effective in a phase II study in patients with moderate to severe CD [79]. Filgotinib subsequently is the first JAK inhibitor to show efficacy in CD. The $48 \%$ clinical remission rate was statistically significant versus placebo after 10 weeks of induction therapy [79]. The placebo response was that only $23 \%$ of patients received a CDI lower than 150 points. Also, for the clinical response which was at a CDI decrease of 100 points or more, there was a difference between placebo (41\%) as the Filgotinib 200 $\mathrm{mg}$ group achieved a clinical response of $60 \%(\mathrm{p}=0.0386)$ [79]. There also was a significant improvement in clinical response as well as in the IBD quality-of-life questionnaire. The Filgotinib safety profile was similar to what has been described previously for other JAK inhibitors [79].

\section{Summary}

In this review, we outlined that the cytokine network is very complex and multiple backup mechanisms exist. This explains why many trials with biologicals that targeted specific cytokines have failed in the past. However, 6 biologicals are currently approved for the treatment of IBD: 4 anti-TNF agents (infliximab and biosimilars, adalimumab, golimumab and certolizumab pegol) and 2 anti-integrin agents (natalizumab and vedolizumab; natalizumab only in the United States and not in Europe)

Beyond anti-TNFs (and anti-integrins), IL-23 strategies will soon be approved and will be available, especially for anti-TNF non-responders and refractory patients.

Anti-IL-6 strategies do have clinical potential but also risks due to the lack of CRP increase and the reported bowel perforations. At the current moment, it remains doubtful whether additional drug-development programs of this therapeutic principal in IBD will be further advanced. JAK inhibitors target several cytokine receptors and represent a promising class of broader and somewhat unspecific anti-cytokine strategies. They will also likely be soon available for the treatment of IBD patients (presumably with Tofacitinib as first-in-class available agent for UC).

Whether further anti-cytokines strategies will have a potential for clinical practice will be elucidated in the future.

\section{Disclosure Statement}

Gerhard Rogler has consulted to Abbot, Abbvie, Augurix, Boehringer, Calypso, FALK, Ferring, Fisher, Genentech, Essex/ MSD, Novartis, Pfizer, Phadia, Roche, UCB, Takeda, Tillots, Vifor, Vital Solutions and Zeller; Gerhard Rogler has received speaker's honoraria from Astra Zeneca, Abbott, Abbvie, FALK, MSD, Phadia, Tillots, UCB, and Vifor; Gerhard Rogler has received educational grants and research grants from Abbot, Abbvie, Ardeypharm, Augurix, Calypso, Essex/MSD, FALK, Flamentera, Novartis, Roche, Takeda, Tillots, UCB and Zeller.

\section{Financial Support}

Supported by grants from the Swiss National Science Foundation to G.R.: the Swiss IBD Cohort Study (grant No. 3347CO-108792).

\section{References} R, Chalmers D, Kothe C, Baert F, Braakman T, Schaible T, Geboes K, Rutgeerts P: Endoscopic and histological healing with infliximab anti-tumor necrosis factor antibodies in Crohn's disease: a European multicenter trial. Gastroenterology 1999;116:1029-1034.

2 Targan SR, Hanauer SB, van Deventer SJ, Mayer L, Present DH, Braakman T, DeWoody KL, Schaible TF, Rutgeerts PJ: A short-term study of chimeric monoclonal antibody cA2 to tumor necrosis factor alpha for Crohn's disease. Crohn's Disease cA2 Study Group. N Engl J Med 1997;337:10291035.

3 Present DH, Rutgeerts P, Targan S, Hanauer SB, Mayer L, van Hogezand RA, Podolsky DK, Sands BE, Braakman T, DeWoody KL, Schaible TF, van Deventer SJ: Infliximab for the treatment of fistulas in patients with Crohn's disease. N Engl J Med 1999;340: 1398-1405. 
4 Rutgeerts P, D’Haens G, Targan S, Vasiliauskas E, Hanauer SB, Present DH, Mayer L, Van Hogezand RA, Braakman T, DeWoody KL, Schaible TF, Van Deventer SJ: Efficacy and safety of retreatment with anti-tumor necrosis factor antibody (infliximab) to maintain remission in Crohn's disease. Gastroenterology 1999;117:761-769.

5 Hanauer SB, Sandborn WJ, Rutgeerts P, Fedorak RN, Lukas M, MacIntosh D, Panaccione R, Wolf D, Pollack P: Human anti-tumor necrosis factor monoclonal antibody (adalimumab) in Crohn's disease: the CLASSIC-I trial. Gastroenterology 2006;130:323-333; quiz 591.

6 Colombel JF, Sandborn WJ, Rutgeerts P, Enns R, Hanauer SB, Panaccione R, Schreiber S, Byczkowski D, Li J, Kent JD, Pollack PF: Adalimumab for maintenance of clinical response and remission in patients with Crohn's disease: the CHARM trial. Gastroenterology 2007;132:52-65.

7 Sandborn WJ, Feagan BG, Stoinov S, Honiball PJ, Rutgeerts P, Mason D, Bloomfield R, Schreiber S; PRECISE 1 Study Investigators: Certolizumab pegol for the treatment of Crohn's disease. N Engl J Med 2007;357:228-238.

8 Schreiber S, Khaliq-Kareemi M, Lawrance IC, Thomsen OØ, Hanauer SB, McColm J, Bloomfield R, Sandborn WJ; PRECISE 2 Study Investigators: Maintenance therapy with certolizumab pegol for Crohn's disease. N Engl J Med 2007;357:239-250.

9 Rutgeerts P, Sandborn WJ, Feagan BG, Reinisch W, Olson A, Johanns J, Travers S, Rachmilewitz D, Hanauer SB, Lichtenstein GR, de Villiers WJ, Present D, Sands BE, Colombel JF: Infliximab for induction and maintenance therapy for ulcerative colitis. N Engl J Med 2005;353:2462-2476.

10 Reinisch W, Sandborn WJ, Hommes DW, D’Haens G, Hanauer S, Schreiber S, Panaccione R, Fedorak RN, Tighe MB, Huang B, Kampman W, Lazar A, Thakkar R: Adalimumab for induction of clinical remission in moderately to severely active ulcerative colitis: results of a randomised controlled trial. Gut 2011;60:780-787.

11 Sandborn WJ, van Assche G, Reinisch W, Colombel JF, D'Haens G, Wolf DC, Kron M, Tighe MB, Lazar A, Thakkar RB: Adalimum$\mathrm{ab}$ induces and maintains clinical remission in patients with moderate-to-severe ulcerative colitis. Gastroenterology 2012;142:257265.e1-e3.

12 Sandborn WJ, Feagan BG, Marano C, Zhang $\mathrm{H}$, Strauss R, Johanns J, Adedokun OJ, Guzzo C, Colombel JF, Reinisch W, Gibson PR, Collins $J$, Järnerot $G$, Hibi $T$, Rutgeerts $P$; PURSUIT-SC Study Group: Subcutaneous golimumab induces clinical response and remission in patients with moderate-to-severe ulcerative colitis. Gastroenterology 2014;146: 85-95; quiz e14-e15.

13 Sandborn WJ, Feagan BG, Marano C, Zhang $\mathrm{H}$, Strauss R, Johanns J, Adedokun OJ, Guzzo C, Colombel JF, Reinisch W, Gibson PR, Col- lins J, Järnerot G, Rutgeerts P; PURSUITMaintenance Study Group: Subcutaneous golimumab maintains clinical response in patients with moderate-to-severe ulcerative colitis. Gastroenterology 2014;146:96-109.e1.

14 Rutgeerts P: Infliximab is the drug we have been waiting for in Crohn's disease. Inflamm Bowel Dis 2000;6:132-136.

15 Rutgeerts P, Van Assche G, Vermeire S: Optimizing anti-TNF treatment in inflammatory bowel disease. Gastroenterology 2004;126: 1593-1610.

16 Blandizzi C, Gionchetti P, Armuzzi A, Caporali R, Chimenti S, Cimaz R, Cimino L, Lapadula G, Lionetti $\mathrm{P}$, Marchesoni A, Marcellusi A, Mennini FS, Salvarani C, Girolomoni $\mathrm{G}$ : The role of tumour necrosis factor in the pathogenesis of immune-mediated diseases. Int J Immunopathol Pharmacol 2014;27(1 suppl):1-10.

17 Nielsen OH, Ainsworth MA: Tumor necrosis factor inhibitors for inflammatory bowel disease. N Engl J Med 2013;369:754-762.

18 Sands BE: Why do anti-tumor necrosis factor antibodies work in Crohn's disease? Rev Gastroenterol Disord 2004;4(suppl 3):S10-S17.

19 Papadakis KA, Targan SR: Tumor necrosis factor: biology and therapeutic inhibitors. Gastroenterology 2000;119:1148-1157.

20 Dinarello CA: Interleukin-1 and tumor necrosis factor: effector cytokines in autoimmune diseases. Semin Immunol 1992;4:133145.

21 Baert FJ, Rutgeerts PR: Anti-TNF strategies in Crohn's disease: mechanisms, clinical effects, indications. Int J Colorectal Dis 1999;14:4751.

22 Chevaux JB, Vavricka SR, Rogler G, Lakatos PL, Schoepfer A, Peyrin-Biroulet L: Mucosal healing with anti-TNF antibodies. Digestion 2012;86(suppl 1):16-22.

23 Pittet V, Rogler G, Michetti P, Fournier N, Vader JP, Schoepfer A, Mottet C, Burnand B, Froehlich F; Swiss Inflammatory Bowel Disease Cohort Study Group: Penetrating or stricturing diseases are the major determinants of time to first and repeat resection surgery in Crohn's disease. Digestion 2013;87: 212-221.

24 Safroneeva E, Vavricka SR, Fournier N, Pittet V, Peyrin-Biroulet L, Straumann A, Rogler G, Schoepfer AM; Swiss IBD Cohort Study Group: Impact of the early use of immunomodulators or TNF antagonists on bowel damage and surgery in Crohn's disease. Aliment Pharmacol Ther 2015;42:977-989.

25 van den Heuvel TR, Jonkers DM, Jeuring SF, Romberg-Camps MJ, Oostenbrug LE, Zeegers MP, Masclee AA, Pierik MJ: Cohort profile: the inflammatory bowel disease South Limburg cohort (IBDSL). Int $\mathrm{J}$ Epidemiol 2015; pii:dyv088.

26 Jeuring SF, Van den Heuvel T, Zeegers M, Hameeteman W, Romberg-Camps M, Oostenbrug LE, Masclee Ad, Jonkers D, Pierik MJ: Disease behavior in Crohn's disease patients diagnosed in the biological era - a Dutch pop- ulation-based IBD-SL cohort study. Gastroenterology 2015;148:S22-S23.

27 Scharl M, Rogler G: Pathophysiology of fistula formation in Crohn's disease. World J Gastrointest Pathophysiol 2014;5:205-212.

28 Lawrance IC, Rogler G, Bamias G, Breynaert C, Florholmen J, Pellino G, Reif S, Speca S, Latella G: Cellular and molecular mediators of intestinal fibrosis. J Crohns Colitis 2015;pii:j.crohns.2014.09.008.

29 Fiocchi C: Genes and 'in-vironment': how will our concepts on the pathophysiology of inflammatory bowel disease develop in the future? Dig Dis 2012;30(suppl 3):2-11.

30 Rogler G: Update in inflammatory bowel disease pathogenesis. Curr Opin Gastroenterol 2004;20:311-317.

31 Rogler G: Interaction between susceptibility and environment: examples from the digestive tract. Dig Dis 2011;29:136-143.

32 Scharl M, Rogler G: Inflammatory bowel disease pathogenesis: what is new? Curr Opin Gastroenterol 2012;28:301-309.

33 Atreya R, Neurath MF: IBD pathogenesis in 2014: molecular pathways controlling barrier function in IBD. Nat Rev Gastroenterol Hepatol 2015;12:67-68.

34 Watson AJ, Hughes KR: TNF- $\alpha$-induced intestinal epithelial cell shedding: implications for intestinal barrier function. Ann N Y Acad Sci 2012;1258:1-8.

35 Ehehalt R, Braun A, Karner M, Füllekrug J, Stremmel W: Phosphatidylcholine as a constituent in the colonic mucosal barrier - physiological and clinical relevance. Biochim Biophys Acta 2010;1801:983-993.

36 Leucht K, Fischbeck A, Caj M, Liebisch G, Hartlieb E, Benes P, Fried M, Humpf HU, Rogler G, Hausmann M: Sphingomyelin and phosphatidylcholine contrarily affect the induction of apoptosis in intestinal epithelial cells. Mol Nutr Food Res 2014;58:782-798.

37 Stremmel W, Ehehalt R, Staffer S, Stoffels S, Mohr A, Karner M, Braun A: Mucosal protection by phosphatidylcholine. Dig Dis 2012; 30(suppl 3):85-91.

38 Ehehalt R, Wagenblast J, Erben G, Lehmann WD, Hinz U, Merle U, Stremmel W: Phosphatidylcholine and lysophosphatidylcholine in intestinal mucus of ulcerative colitis patients. A quantitative approach by nanoElectrospray-tandem mass spectrometry. Scand J Gastroenterol 2004;39:737-742.

39 Karner M, Kocjan A, Stein J, Schreiber S, von Boyen G, Uebel P, Schmidt C, Kupcinskas L, Dina I, Zuelch F, Keilhauer G, Stremmel W: First multicenter study of modified release phosphatidylcholine 'LT-02' in ulcerative colitis: a randomized, placebo-controlled trial in mesalazine-refractory courses. Am J Gastroenterol 2014;109:1041-1051.

40 Stremmel W, Braun A, Hanemann A, Ehehalt R, Autschbach F, Karner M: Delayed release phosphatidylcholine in chronic-active ulcerative colitis: a randomized, double-blinded, dose finding study. J Clin Gastroenterol 2010; 44:e101-e107. 
41 Stremmel W, Hanemann A, Braun A, Stoffels S, Karner M, Fazeli S, Ehehalt R: Delayed release phosphatidylcholine as new therapeutic drug for ulcerative colitis - a review of three clinical trials. Expert Opin Investig Drugs 2010;19:1623-1630.

42 Stremmel W, Merle U, Zahn A, Autschbach F, Hinz U, Ehehalt R: Retarded release phosphatidylcholine benefits patients with chronic active ulcerative colitis. Gut 2005;54:966971.

43 Wehkamp J, Stange EF, Fellermann K: Defensin-immunology in inflammatory bowel disease. Gastroenterol Clin Biol 2009;33(suppl 3):S137-S144.

44 Kübler I, Koslowski MJ, Gersemann M, Fellermann K, Beisner J, Becker S, Rothfuss K, Herrlinger KR, Stange EF, Wehkamp J: Influence of standard treatment on ileal and colonic antimicrobial defensin expression in active Crohn's disease. Aliment Pharmacol Ther 2009;30:621-633.

45 Bevins CL, Stange EF, Wehkamp J: Decreased Paneth cell defensin expression in ileal Crohn's disease is independent of inflammation, but linked to the NOD2 1007 fs genotype. Gut 2009;58:882-883; discussion 883884.

46 Wehkamp J, Koslowski M, Wang G, Stange EF: Barrier dysfunction due to distinct defensin deficiencies in small intestinal and colonic Crohn's disease. Mucosal Immunol 2008; 1(suppl 1):S67-S74.

47 Wang G, Stange EF, Wehkamp J: Host-microbe interaction: mechanisms of defensin deficiency in Crohn's disease. Expert Rev Anti Infect Ther 2007;5:1049-1057.

48 Wehkamp J, Schmid M, Fellermann K, Stange EF: Defensin deficiency, intestinal microbes, and the clinical phenotypes of Crohn's disease. J Leukoc Biol 2005;77:460-465.

49 Fellermann K, Wehkamp J, Herrlinger KR, Stange EF: Crohn's disease: a defensin deficiency syndrome? Eur J Gastroenterol Hepatol 2003; 15:627-634.

50 Wehkamp J, Salzman NH, Porter E, Nuding $S$, Weichenthal M, Petras RE, Shen B, Schaeffeler E, Schwab M, Linzmeier R, Feathers RW, Chu H, Lima H Jr, Fellermann K, Ganz T, Stange EF, Bevins CL: Reduced Paneth cell alpha-defensins in ileal Crohn's disease. Proc Natl Acad Sci U S A 2005;102:18129-18134.

51 Ruiz PA, Morón B, Becker HM, Lang S, Atrott K, Spalinger MR, Scharl M, Wojtal KA, Fischbeck-Terhalle A, Frey-Wagner I, Hausmann M, Kraemer T, Rogler G: Titanium dioxide nanoparticles exacerbate DSS-induced colitis: role of the NLRP3 inflammasome. Gut 2016;pii:gutjnl-2015-310297.

52 Anderson CA, Boucher G, Lees CW, Franke A, D'Amato M, Taylor KD, Lee JC, Goyette P, Imielinski M, Latiano A, Lagacé C, Scott R, Amininejad L, Bumpstead S, Baidoo L, Baldassano RN, Barclay M, Bayless TM, Brand S, Buning C, Colombel JF, Denson LA, De Vos M, Dubinsky M, Edwards C, Ellinghaus D, Fehrmann RS, Floyd JA, Florin T, Franchi- mont D, Franke L, Georges M, Glas J, Glazer NL, Guthery SL, Haritunians T, Hayward NK, Hugot JP, Jobin G, Laukens D, Lawrance I, Lemann M, Levine A, Libioulle C, Louis E, McGovern DP, Milla M, Montgomery GW, Morley KI, Mowat C, Ng A, Newman W, Ophoff RA, Papi L, Palmieri O, Peyrin-Biroulet L, Panes J, Phillips A, Prescott NJ, Proctor DD, Roberts R, Russell R, Rutgeerts P, Sanderson J, Sans M, Schumm P, Seibold F, Sharma Y, Simms LA, Seielstad M, Steinhart AH, Targan SR, van den Berg LH, Vatn M, Verspaget $\mathrm{H}$, Walters $\mathrm{T}$, Wijmenga $\mathrm{C}$, Wilson DC, Westra HJ, Xavier RJ, Zhao ZZ, Ponsioen CY, Andersen V, Torkvist L, Gazouli M, Anagnou NP, Karlsen TH, Kupcinskas L, Sventoraityte J, Mansfield JC, Kugathasan S, Silverberg MS, Halfvarson J, Rotter JI, Mathew CG, Griffiths AM, Gearry R, Ahmad T, Brant SR, Chamaillard M, Satsangi J, Cho JH, Schreiber S, Daly MJ, Barrett JC, Parkes M, Annese V, Hakonarson H, Radford-Smith G, Duerr RH, Vermeire S, Weersma RK, Rioux JD: Meta-analysis identifies 29 additional ulcerative colitis risk loci, increasing the number of confirmed associations to 47 . Nat Genet 2011;43:246-252.

53 Franke A, McGovern DP, Barrett JC, Wang K, Radford-Smith GL, Ahmad T, Lees CW, Balschun T, Lee J, Roberts R, Anderson CA, Bis JC, Bumpstead S, Ellinghaus D, Festen EM, Georges M, Green T, Haritunians T, Jostins L, Latiano A, Mathew CG, Montgomery GW, Prescott NJ, Raychaudhuri S, Rotter JI, Schumm P, Sharma Y, Simms LA, Taylor KD, Whiteman D, Wijmenga C, Baldassano RN, Barclay M, Bayless TM, Brand S, Buning C, Cohen A, Colombel JF, Cottone M, Stronati L, Denson T, De Vos M, D'Inca R, Dubinsky M, Edwards C, Florin T, Franchimont D, Gearry R, Glas J, Van Gossum A, Guthery SL, Halfvarson J, Verspaget HW, Hugot JP, Karban A, Laukens D, Lawrance I, Lemann M, Levine A, Libioulle C, Louis E, Mowat C, Newman W, Panes J, Phillips A, Proctor DD, Regueiro M, Russell R, Rutgeerts P, Sanderson J, Sans M, Seibold F, Steinhart AH, Stokkers PC, Torkvist L, Kullak-Ublick G, Wilson D, Walters T, Targan SR, Brant SR, Rioux JD, D'Amato M, Weersma RK, Kugathasan S, Griffiths AM, Mansfield JC, Vermeire S, Duerr RH, Silverberg MS, Satsangi J, Schreiber S, Cho JH, Annese V, Hakonarson H, Daly MJ, Parkes M: Genome-wide meta-analysis increases to 71 the number of confirmed Crohn's disease susceptibility loci. Nat Genet 2010;42:1118-1125.

54 Jostins L, Ripke S, Weersma RK, Duerr RH, McGovern DP, Hui KY, Lee JC, Schumm LP, Sharma Y, Anderson CA, Essers J, Mitrovic M, Ning K, Cleynen I, Theatre E, Spain SL, Raychaudhuri S, Goyette P, Wei Z, Abraham C, Achkar JP, Ahmad T, Amininejad L, Ananthakrishnan AN, Andersen V, Andrews JM, Baidoo L, Balschun T, Bampton PA, Bitton A, Boucher G, Brand S, Buning C, Cohain A, Cichon S, D’Amato M, De Jong D, Dev- aney KL, Dubinsky M, Edwards C, Ellinghaus D, Ferguson LR, Franchimont D, Fransen K, Gearry R, Georges M, Gieger C, Glas J, Haritunians T, Hart A, Hawkey C, Hedl M, Hu X, Karlsen TH, Kupcinskas L, Kugathasan S, Latiano A, Laukens D, Lawrance IC, Lees CW, Louis E, Mahy G, Mansfield J, Morgan AR, Mowat C, Newman W, Palmieri O, Ponsioen CY, Potocnik U, Prescott NJ, Regueiro M, Rotter JI, Russell RK, Sanderson JD, Sans M, Satsangi J, Schreiber S, Simms LA, Sventoraityte J, Targan SR, Taylor KD, Tremelling M, Verspaget HW, De Vos M, Wijmenga C, Wilson DC, Winkelmann J, Xavier RJ, Zeissig S, Zhang B, Zhang CK, Zhao H; International IBD Genetics Consortium (IIBDGC), Silverberg MS, Annese V, Hakonarson H, Brant SR, Radford-Smith G, Mathew CG, Rioux JD, Schadt EE, Daly MJ, Franke A, Parkes M, Vermeire S, Barrett JC, Cho JH: Host-microbe interactions have shaped the genetic architecture of inflammatory bowel disease. Nature 2012;491:119-124.

55 Neurath MF: Cytokines in inflammatory bowel disease. Nat Rev Immunol 2014;14: 329-342.

56 Vicini P, Fields O, Lai E, Litwack ED, Martin AM, Morgan TM, Pacanowski MA, Papaluca M, Perez OD, Ringel MS, Robson M, Sakul H, Vockley J, Zaks T, Dolsten M, Sogaard M: Precision medicine in the age of big data: the present and future role of large-scale unbiased sequencing in drug discovery and development. Clin Pharmacol Ther 2016;99:198-207.

57 Aronson SJ, Rehm HL: Building the foundation for genomics in precision medicine. Nature 2015;526:336-342.

58 Lopez J, Harris S, Roda D, Yap TA: Precision medicine for molecularly targeted agents and immunotherapies in early-phase clinical trials. Transl Oncogenomics 2015;7(suppl 1):111.

59 Rappaport SM: Genetic factors are not the major causes of chronic diseases. PLoS One 2016;11:e0154387.

60 Schett G, Elewaut D, McInnes IB, Dayer JM, Neurath MF: How cytokine networks fuel inflammation: toward a cytokine-based disease taxonomy. Nat Med 2013;19:822-824.

61 Andoh A, Yagi Y, Shioya M, Nishida A, Tsujikawa T, Fujiyama Y: Mucosal cytokine network in inflammatory bowel disease. World J Gastroenterol 2008;14:5154-5161.

62 Fuss IJ: Cytokine network in inflammatory bowel disease. Curr Drug Targets Inflamm Allergy 2003;2:101-112.

63 Scharl M, Vavricka SR, Rogler G: Review: new anti-cytokines for IBD: what is in the pipeline? Curr Drug Targets 2013;14:1405-1420.

64 Sandborn WJ, Gasink C, Gao LL, Blank MA, Johanns J, Guzzo C, Sands BE, Hanauer SB, Targan S, Rutgeerts P, Ghosh S, de Villiers WJ, Panaccione R, Greenberg G, Schreiber S, Lichtiger S, Feagan BG; CERTIFI Study Group: Ustekinumab induction and maintenance therapy in refractory Crohn's disease. N Engl J Med 2012;367:1519-1528. 
65 Sandborn WJ, Feagan BG, Fedorak RN, Scherl E, Fleisher MR, Katz S, Johanns J, Blank M, Rutgeerts P; Ustekinumab Crohn's Disease Study Group: A randomized trial of Ustekinumab, a human interleukin-12/23 monoclonal antibody, in patients with moderate-to-severe Crohn's disease. Gastroenterology 2008;135:1130-1141.

66 Wils P, Bouhnik Y, Michetti P, Flourie B, Brixi H, Bourrier A, Allez M, Duclos B, Grimaud JC, Buisson A, Amiot A, Fumery M, Roblin X, Peyrin-Biroulet L, Filippi J, Bouguen G, Abitbol V, Coffin B, Simon M, Laharie D, Pariente B; Groupe d'Etude Thérapeutique des Affections Inflammatoires du Tube Digestif: Subcutaneous ustekinumab provides clinical benefit for two-thirds of patients with Crohn's disease refractory to anti-tumor necrosis factor agents. Clin Gastroenterol Hepatol 2016;14:242-250.e1-e2.

67 Feagan BG, Gasink C, Lang Y, Friedman JR, Johanns J, Gao LL, Sands B, Hanauer S, Rutgeerts $\mathrm{P}$, Targan S, Ghosh S, de Villiers W, Colombel JF, Tulassay Z, Seidler U, Sandborn WJ: A multicenter, randomized, double-blind, placebo-controlled phase 3 study of ustekinumab, a human monoclonal antibody to IL-12/23p 40 , in patients with moderately severe active Crohn's disease who are naïve or not refractory to anti-TNFa: uniti-2. United European Gastroenterol J 2015:abstract LB4.

68 Sands BE, Chen J, Penney M, Newbold P, Faggioni R, van der Merwe R, Patra K, Kle- kotka P, Pulkstenis E, Drappa J, Gasser RA: Initial evaluation of MEDI2070 (specific antiIL-23 antibody) in patients with active Crohn's disease who have failed anti-TNF antibody therapy: a randomized, doubleblind placebo-controlled phase $2 \mathrm{a}$ induction study. Gastroenterology 2015;148:S163S164.

69 Rath T, Billmeier U, Waldner MJ, Atreya R, Neurath MF: From physiology to disease and targeted therapy: interleukin-6 in inflammation and inflammation-associated carcinogenesis. Arch Toxicol 2015;89:541-554.

70 Rossi JF, Lu ZY, Jourdan M, Klein B: Interleukin- 6 as a therapeutic target. Clin Cancer Res 2015;21:1248-1257.

71 Wolf J, Rose-John S, Garbers C: Interleukin-6 and its receptors: a highly regulated and dynamic system. Cytokine 2014;70:11-20.

72 Tanaka T, Kishimoto T: The biology and medical implications of interleukin-6. Cancer Immunol Res 2014;2:288-294.

73 Scheller J, Garbers C, Rose-John S: Interleukin-6: from basic biology to selective blockade of pro-inflammatory activities. Semin Immunol 2014;26:2-12.

74 Yao X, Huang J, Zhong H, Shen N, Faggioni R, Fung M, Yao Y: Targeting interleukin-6 in inflammatory autoimmune diseases and cancers. Pharmacol Ther 2014;141:125-139.

75 Ito H, Takazoe M, Fukuda Y, Hibi T, Kusugami K, Andoh A, Matsumoto T, Yamamura T, Azuma J, Nishimoto N, Yoshizaki K, Shimoyama T, Kishimoto T: A pilot randomized trial of a human anti-interleukin- 6 receptor monoclonal antibody in active Crohn's disease. Gastroenterology 2004;126:989-996; discussion 947.

76 Danese S, Vermeire S, Hellstern P, Panaccione R, Rogler G, Fraser G, Kohn A, Desreumaux P, Leong RW, Comer GM, Cataldi F, Banerjee A, Maguire MK, Li C, Rath N, Beebe J, Schreiber SW: Results of ANDANTE, a randomised clinical study with an anti-IL6 antibody (PF-04236921) in subjects with Crohn's disease who are anti-tumour necrosis factor inadequate responders. J Crohns Colitis 2016:abstract OP015.

77 Boland BS, Sandborn WJ, Chang JT: Update on Janus kinase antagonists in inflammatory bowel disease. Gastroenterol Clin North Am 2014;43:603-617.

78 Sandborn WJ, Ghosh S, Panes J, Vranic I, Su C, Rousell S, Niezychowski W; Study A3921063 Investigators: Tofacitinib, an oral janus kinase inhibitor, in active ulcerative colitis. N Engl J Med 2012;367:616624

79 Vermeire S, Schreiber S, Petryka R, Kuehbacher T, Hebuterne X, Roblin X, Klopocka $\mathrm{M}$, Goldis E, Wisniewska-Jarosinska M, Baranovsky A, Sike R, Tasset C, Van der Aa A, Harrison P: Filgotinib, a selective JAK1 inhibitor, induces clinical remission in patients with moderate-to-severe Crohn's disease: interim analysis from the phase 2 FITZROY study. J Crohns Colitis 2016:abstract OP020. 